\title{
Indikasi Cekaman Gulma Bidens Pilosa L. Akibat Perlakuan Perasan Pilea Microphylla L.
}

\section{Stress Indication on Bidens Pilosa L. Cause of Pilea Microphylla L. Extract Treatment}

\author{
Elisabeth Sabatini Siagian ${ }^{1} *$, Sri Darmanti ${ }^{2}$, Rini Budihastuti ${ }^{2}$ \\ ${ }^{1}$ Program Studi Biologi, Departemen Biologi, Fakultas Sains dan Matematika, Universitas Diponegoro \\ ${ }^{2}$ Departemen Biologi, Fakultas Sains dan Matematika, Universitas Diponegoro \\ Jl. Prof. Soedarto, SH, Tembalang, Semarang \\ *Email :siagianelis@gmail.com
}

Diterima 8 Juni 2017 / Disetujui 26 Agustus 2017

\begin{abstract}
ABSTRAK
Bidens pilosa L. merupakan salah satu tanaman gulma yang biasa ditemukan di daerah perkebunan yang mengganggu tanaman budidaya. Pilea microphylla L merupakan tanaman yang memiliki potensi sebagai herbisida alami untuk pengendali gulma. Penelitian ini bertujuan untuk mengkaji pengaruh pemberian alelokimia perasan Pilea microphylla L. terhadap akumulasi superoksida dan pertumbuhan vegetatif Bidens pilosa L. Penelitian menggunakan Rancangan Acak Lengkap (RAL) satu faktor yaitu konsentrasi perasan alelokimia Pilea microphylla L yaitu $0 \% ; 12,5 \% ; 25 \% ; 37,5 \%$ dan 50\%. Data dianalisis dengan Analisys of Variance (ANOVA) dilanjutkan dengan uji Duncan's Multiple Test (DMRT) pada taraf kepercayaan 95\%. Hasil penelitian menunjukkan semakin tinggi konsentrasi perasan alelokimia Pilea microphylla L. semakin meningkatkan akumulasi superoksida dan menurunkan tinggi tanaman, jumlah daun, luas daun, bobot segar dan bobot kering tanaman, bobot segar dan bobot kering akar, bobot segar dan bobot kering batang, bobot segar dan bobot kering daun serta rasio tajuk akar.
\end{abstract}

Kata kunci : Bidens pilosa L., alelokimia, Pilea microphylla,L., superoksida, pertumbuhan vegetatif

\section{ABSTRACT}

Bidens pilosa $\mathrm{L}$. is one of the weed plants commonly found in plantation areas that interfere with cultivated plants. Pilea microphylla $\mathrm{L}$ is a plant that has potential as a natural herbicide for weed control. This study aims to examine the effect of Alleochemical Pilea microphylla L. extract on superoxide accumulation and vegetative growth of Bidens pilosa L. The study used Completely Randomized Design (RAL) of one factor, ie Alleochemical extract concentration of Pilea microphylla L ie $0 \% ; 12.5 \% ; 25 \% ; 37.5 \%$ and $50 \%$.This study were analyzed by Analisys of Variance (ANOVA) followed by Duncan's Multiple Test (DMRT) test at 95\% confidence level. The results showed that the higher concentration of alleochemical extract of Pilea microphylla L. gave significant effect in increasing superoxide accumulation and decreased plant height, leaf number, leaf area, fresh weight and dry weight of plant, fresh weight and root dry weight, fresh weight and dry weight of stem, fresh weight and leaf dry weight and root shoot ratio.

Keywords: Bidens pilosa L., allelochemical, Pilea microphylla L., superoxide, vegetative growth

\section{PENDAHULUAN}

Pilea microphylla L dikenal sebagai gulma. Menurut Cnover dan Stamps (1994), Pilea microphylla L. biasanya ditemukan di tempat lembab menumpang pada tanaman lain dalam pot atau disekitar perkebunan. Pilea microphylla $\mathrm{L}$ dapat menghambat pertumbuhan tanaman lain karena diduga mampu menghasilkan alelokimia berupa senyawa fenol sehingga berpotensi sebagai herbisida alami. Hasil penelitian Greeshma et al (2015) dengan metode HPLC menunjukkan kendungan senyawa fenolik pada Pilea microphylla L. adalah 211,553 $\mu \mathrm{g} / \mathrm{g}$ asam klorogenat, 0,569 $\mu \mathrm{g} / \mathrm{g}$ asam sinapik, $0,744 \mu \mathrm{g} / \mathrm{g}$ asam kumarat, $7,784 \mu \mathrm{g} / \mathrm{g}$ asam hidroksil benzoat, $81,331 \mu \mathrm{g} / \mathrm{g}$ asam galat, 211,553 $\mu \mathrm{g} / \mathrm{g}$ asam 
vanillat, $211,553 \mu \mathrm{g} / \mathrm{g}$ asam sinamat, $241,775 \mu \mathrm{g} / \mathrm{g}$ catechol dan $1,686 \mathrm{mg} / \mathrm{g}$ asam ferulat.

Bidens pilosa L. merupakan gulma menahun yang berasal dari Amerika Selatan yang menyebar keluruh daerah tropis dan subtropis. Gulma adalah tumbuhan yang kehadirannya tidak diinginkan karena dapat menghambat pertumbuhan tanaman budidaya. Bidens pilosa L. biasanya tumbuh diantara semak-semak, daerah perkebunan, tepi jalan atau lahan kosong yang tidak dipelihara (Bartolome et al, 2013).

The International Allelopathy Societytahun 1996 mendifinisikan alelopati sebagai proses yang melibatkan metabolik sekunder yang dihasilkan oleh tanaman, algae, bakteri dan fungi. Senyawa yang dihasilkan disebut alelokimia (Roger et al, 2006), termasuk diantaranya adalah kumarin, benzokuinon, terpenoid, glukosinolat dan tanin. Alelokimia banyak ditemukan pada tumbuhan berkayu, herba dan rumput (Kelton, 2012).

Fenol merupakan senyawa yang bersifat polar, umumnya ditemukan pada kingdom Plantae. Riswiyanto (2009) menyatakan bahwa fenol merupakan senyawa dengan gugus $-\mathrm{OH}$ yang terikat langsung pada gugus aromatic dengan titik didih $181,9^{\circ} \mathrm{C}$. Beberapa senyawa fenolikn yang memiliki sifat alelopati antara lain klorogenat, asam galat, $p$-hydroxybenzoic, protocatechuic, caffeic, 3,5-dinitrozenzoic acids, 3,4dihydroxybenzaldehyde, asam $p$-kumarat, asam ferulat, dan asam anisic. Penelitian Li et al. (2010) menunjukkan terjadinya gangguan pembelahan sel dan kerusakan struktur selular pada tanaman yang terkena asam fenolik. Tanaman yang mendapat cekaman fenol mengalami peningkatan produksi Reactive Oxygen Species (ROS) berupa $\mathrm{O}_{2}^{-}, \mathrm{H}_{2} \mathrm{O}_{2}$ dan $\mathrm{OH}$, yaitu senyawa oksidan yang sangat reaktif sehingga dapat menyebabkan kerusakan komponen sel.

Penelitian ini bertujuan mengkaji Indikasi Cekaman Bidens Pilosa L. akibat Perlakuan Perasan Pilea Microphylla L.

\section{METODE PENELITIAN}

Bahan yang digunakan: benih Bidens pilosa L. dan gulma Pilea microphyla L. yang diperoleh di lingkungan Universitas Diponegoro, air, media tanam, aquades, ethanol $96 \%, \mathrm{Na}_{2} \mathrm{CO}_{3}$, asam galat,reagen Folin-Ciocalteu, buffer fosfat, $\mathrm{NaN}_{3}$ dan NBT (nitro blue tetrazolium). Alat yang digunakan: timbangan analitik, spektrofotometer UV-VIS, mortar, icebath, dan gelas ukur.

Pembuatan perasan Alelokimia Pilea microphyla L. bersadarkan metode Yonli et al (2010) dan Darmanti (2015), gulma dikeringanginkan di tempat gelap kemudian di blender menggunakan air dengan perbandingan berat/volume yaitu1 : 1 untuk mendapatkan perasan $100 \%$. PerasanPilea microphyla L. kemudian diencerkan sesuai konsentrasi perlakuan, yaitu $25 \%, 50 \%$, dan $75 \%$.

Penanaman dan perlakuan: biji Bidens pilosa L. disebar di permukaan media tanam kemudian disiram air. Setelah umur 28 hari, tanaman diseleksi berdasarkan tinggi dan jumlah daun yang sama. Tanaman yang telah diseleksi, diaklimatisasi selama satu minggu. Perlakuan pada Bidens pilosa L. dilakukan selama 36 hari dimulai pada umur 35 hari setelah tanam.

Penentuan kadar fenol total gulma Pilea microphylla L. berdasarkan metode Bhaskar, et al (2011). Pilea microphyla L. sebanyak 0,5 g. digerus dan ditambahkan $5 \mathrm{ml}$ metanol PA. Ekstrak diambil sebanyak $20 \mu 1$ dan ditambahkan $1,58 \mathrm{ml}$ aquades dan $100 \mu \mathrm{l}$ reagen Folin-Ciocalteu, selanjutnya diinkubasi dalam suhu ruang selama 8 menit. Kemudian ditambahkan $300 \mu 1 \quad \mathrm{Na}_{2} \mathrm{CO}_{3}$ $7,5 \%$ w/v dan diinkubasi pada suhu $30^{\circ} \mathrm{C}$ selama 30 menit. Absorbansi ditentukan pada $\lambda 769 \mathrm{~nm}$ dengan menggunakan spektrofotometer UV-Vis.

Penentuan kadar superoksida berdasarkan metode Malecka et al (2011). Sampel daun Bidens pilosa L. sebanyak 0,143 g dimasukkan ke dalam microtube kemudian ditambahkan buffer fosfat $50 \mathrm{mM}$ pH 7,8 sebanyak $2 \mathrm{ml}$ yang mengandung $10 \mathrm{mM} \mathrm{NaN}_{3}$ dan $0.05 \%$ NBT (nitro blue tetrazolium). Sampel diinkubasi dalam gelap pada suhu ruang. Larutan diambil sebanyak $2 \mathrm{~mL}$ kemudian dipanaskan menggunakan waterbath pada suhu $85^{\circ} \mathrm{C}$ selama 10 menit kemudian didinginkan pada ice bath selama 5 menit. Absorbansi larutan uji diukur pada $\lambda 589 \mathrm{~nm}$ menggunakan spektrofotometer UV-Vis. Data yang diperoleh dianalisis dengan analisa 
sidik ragam (ANOVA) pada nilai signifikansi $95 \%$.

\section{HASIL DAN PEMBAHASAN}

Hasil pengujian fenol total ekstrak gulma Pilea microphylla L. dengan metode spektrofotometri adalah $8,242 \mu \mathrm{g} / \mathrm{g}$. Li et al (2010), menyatakan bahwa asam fenolik menyebabkan gangguan pembelahan sel dan kerusakan struktur selular pada tanaman. Alelokimia fenolik menyebabkan cekaman pada tanaman sehingga meningkatkan produksi ROS yang dapat menghambat proses penyerapan ion dan air, pembentukan enzim dan hormon, sintesis protein respirasi dan fotosintesis yang mengakibatkan petumbuhan dan perkembangan tanaman terhambat.

Hasil uji ANOVA menunjukkan bahwa perlakuan perasan Pilea microphylla L pada gulma Bidens pilosa L. meningkatkan kandungan superoksida (Gambar 1). Semakin tinggi konsentrasi perlakuan, kandungan superoksida semakin meningkat.

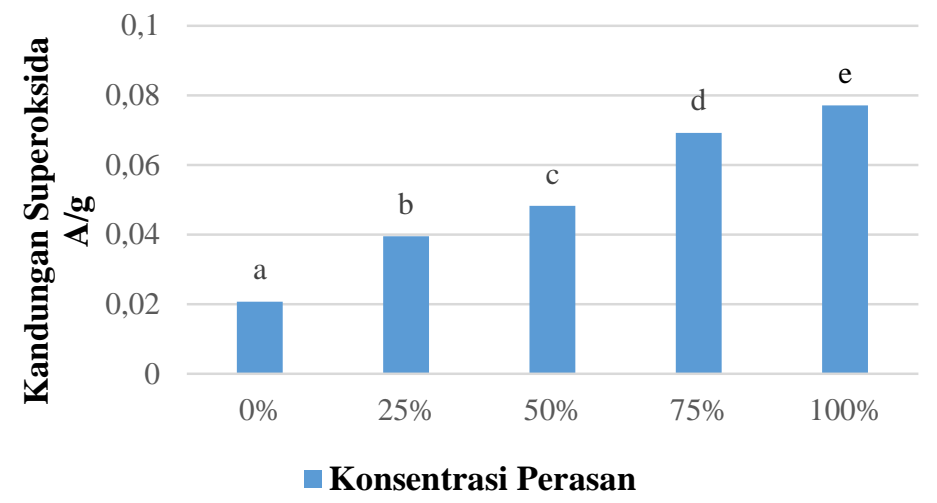

Gambar 1. Kandungan superoksida daun Bidens pilosa L. akibat perlakuan perasan Pilea microphylla L. pada konsentrasi $0 \%, 25 \%, 50 \%, 75 \%$ dan 100\%, setelah 36 hari perlakuan.

Alelokimia senyawa fenolik dari perasanPilea microphylla L. menyebabkan cekaman oksidatif yang dapat meningkatkan jumlah produksi ROS berupa senyawa anion superoksida. Gambar 1 menunjukkan bahwa semakin tinggi konsentrasi perasan Pilea microphylla L., maka kandungan superoksida juga semakin meningkat. Nurhayati dkk (2011) menyatakan bahwa superoksida merupakan radikal bebas berupa molekul yang memiliki elektron tidak berpasangan, sehingga bersifat sangat reaktif dan dapat menyebabkan kerusakan sel. Superoksida pada konsentrasi tinggi dapat merusak komponen-komponen seluler dan makromolekul termasuk membran plasma, asam nukleat dan protein. Hal ini akan mengganggu proses fisiologis pada tanaman yang dapat menyebabkan penurunan laju pertumbuhan hingga kematian tanaman (Malecka, 2009).

Hasil uji ANOVA pada taraf signifikansi 95\%, menunjukkan bahwa perlakuan perasan Pilea microphylla L berpengaruh nyata terhadap pertumbuhan vegetatif gulma Bidens pilosa $\mathrm{L}$. meliputi tinggi, jumlah daun, luas daun, bobot segar dan bobot kering serta rasio tajuk akar.

Perlakuan perasanPilea microphylla L. menunjukkan hasil berbeda nyata pada tinggi gulma Bidens pilosa L., tetapi perlakuan antara konsentrasi $75 \%$ dan $100 \%$ tidak menunjukkan perbedaan yang nyata (gambar 2). Gambar 3 menunjukkan bahwa larutan perasan Pilea microphylla L. menghambat pertambahan jumlah daun tanaman Bidens pilosa L, tetapi antara perlakuan 25\%, 50\%, 75\% dan $100 \%$ tidak menunjukkan perbedaan yang nyata. Perlakuan perasan Pilea microphylla L. Gambar 4. menunjukkan perlakuan alelokima dari perasan Pilea microphylla L. menyebabkan penurunan luas daun Bidens pilosa L. Luas permukaan daun terbesar pada perlakuan kontrol sedangkan perlakuan $100 \%$ menunjukkan luas daun yang paling kecil. 


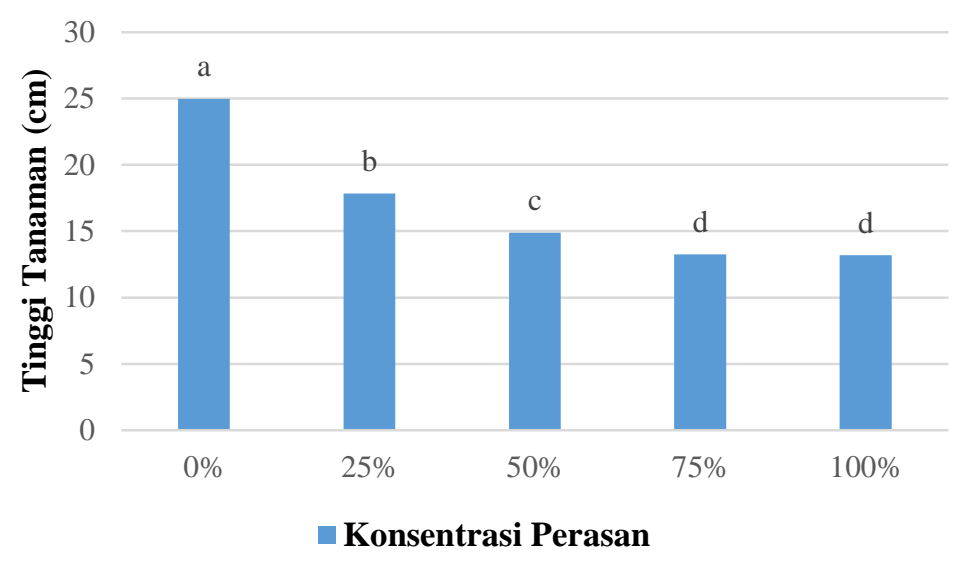

Gambar 2. Tinggi gulma Bidens pilosa L. akibat perlakuan pereasan Pilea microphylla L. pada konsentrasi $0 \%, 25 \%, 50 \%, 75 \%$ dan $100 \%$ setelah 36 hari perlakuan

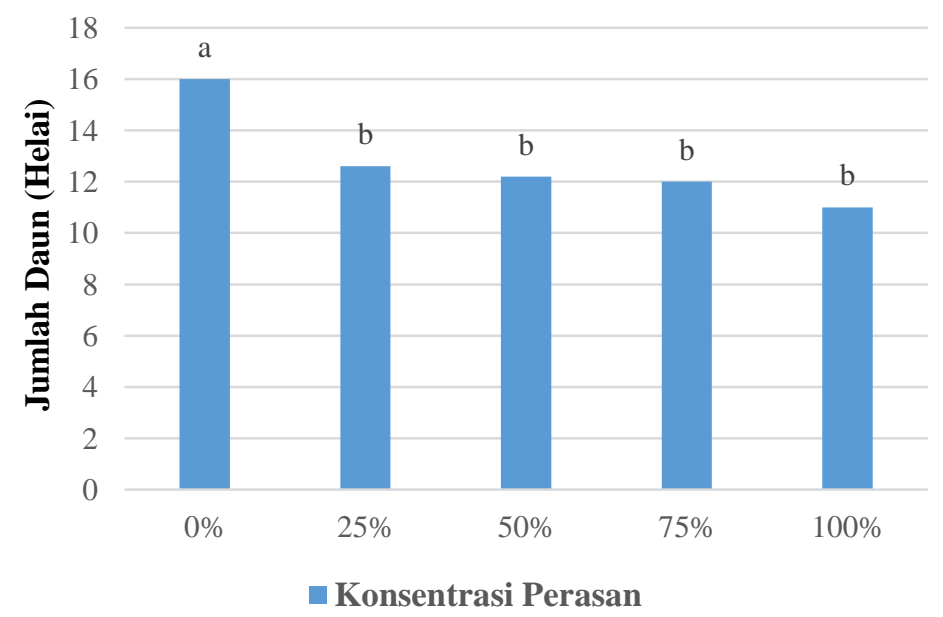

Gambar 3. Jumlah Daun Bidens pilosa L. akibat perlakuan perasan Pilea microphylla L. pada konsentrasi 0\%, $25 \%, 50 \%, 75 \%$ dan $100 \%$ setelah 36 hari perlakuan.

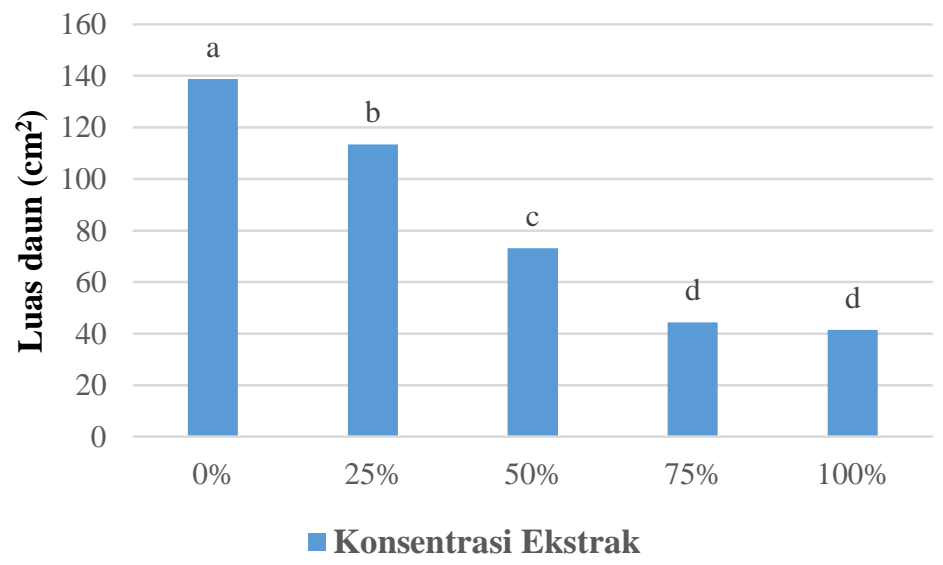

Gambar 4. Luas daun $\left(\mathrm{Cm}^{2}\right)$ Bidens pilosa L. akibat perlakuan perasan Pilea microphylla L. pada konsentrasi $0 \%, 25 \%, 50 \%, 75 \%$ dan $100 \%$ setelah 36 hari perlakuan 
Tabel 1. Bobot segar dan bobot kering akar, batang, daun dan total gulma Bidens pilosa L. akibat perlakuan perasan Pilea microphylla L. pada konsentrasi 0\%, 25\%, 50\%, 75\% dan 100\% setelah 36 hari perlakuan.

\begin{tabular}{llllllllll}
\hline \multirow{2}{*}{ erlakuan } & $\begin{array}{l}\text { Bobot } \\
\text { segar } \\
\text { Akar }\end{array}$ & $\begin{array}{l}\text { Bobot } \\
\text { kering } \\
\text { Akar }\end{array}$ & $\begin{array}{l}\text { Bobot } \\
\text { segar } \\
\text { Batang }\end{array}$ & $\begin{array}{l}\text { Bobot } \\
\text { kering } \\
\text { Batang }\end{array}$ & $\begin{array}{l}\text { Bobot } \\
\text { segar } \\
\text { Daun }\end{array}$ & $\begin{array}{l}\text { Bobot } \\
\text { kering } \\
\text { Daun }\end{array}$ & $\begin{array}{l}\text { Bobot } \\
\text { segar } \\
\text { Total }\end{array}$ & $\begin{array}{l}\text { Bobot } \\
\text { kering } \\
\text { Total }\end{array}$ & $\begin{array}{l}\text { Rasio } \\
\text { Tajuk } \\
\text { Akar }\end{array}$ \\
\hline $0 \%$ & $2,346^{\mathrm{a}}$ & $0,460^{\mathrm{f}}$ & $2.160^{\mathrm{a}}$ & $0.234^{\mathrm{f}}$ & $2,166^{\mathrm{a}}$ & $0,254^{\mathrm{f}}$ & $5,808^{\mathrm{a}}$ & $0,948^{\mathrm{f}}$ & $6.60^{\mathrm{a}}$ \\
$25 \%$ & $1,390^{\mathrm{b}}$ & $0,296^{\mathrm{f}}$ & $0,850^{\mathrm{b}}$ & $0,178^{\mathrm{g}}$ & $1,848^{\mathrm{b}}$ & $0,222^{\mathrm{g}}$ & $4,028^{\mathrm{b}}$ & $0,696^{\mathrm{g}}$ & $7.11^{\mathrm{a}}$ \\
$50 \%$ & $0,682^{\mathrm{c}}$ & $0,132^{\mathrm{g}}$ & $0,536^{\mathrm{c}}$ & $0,090^{\mathrm{h}}$ & $1,004^{\mathrm{c}}$ & $0,112^{\mathrm{h}}$ & $2,202^{\mathrm{c}}$ & $0,334^{\mathrm{h}}$ & $7.52^{\mathrm{ab}}$ \\
$75 \%$ & $0,452^{\mathrm{d}}$ & $0,102^{\mathrm{h}}$ & $0,380^{\mathrm{d}}$ & $0,064^{\mathrm{i}}$ & $0,812^{\mathrm{d}}$ & $0,088^{\mathrm{i}}$ & $1,664^{\mathrm{d}}$ & $0,254^{\mathrm{i}}$ & $8.10^{\mathrm{b}}$ \\
$100 \%$ & $0,266^{\mathrm{e}}$ & $0,074^{\mathrm{i}}$ & $0,312^{\mathrm{e}}$ & $0,044^{\mathrm{j}}$ & $0,608^{\mathrm{e}}$ & $0,050^{\mathrm{j}}$ & $1.160^{\mathrm{e}}$ & $0,166^{\mathrm{j}}$ & $9.87^{\mathrm{c}}$ \\
\hline
\end{tabular}

Keterangan: Angka yang ditandai huruf yang sama pada kolom yang sama menunjukkan tidak berbeda nyata dengan uji DMRT pada taraf $95 \%$

Tabel 1 menunjukkan bahwa semua konsentrasi perlakuan menurunkan total bobot segar dan bobot kering Bidens pilosa L. serta bobot segar dan bobot kering akar, batang dan daun gulma Bidens pilosa L. Bobot segar akar, batang daun dan total serta bobot kering akar, batang daun dan total gulma Bidens pilosa L. berbeda nyata pada perlakuan $0 \% ; 25 \%$; $50 \%$; $75 \%$ dan $100 \%$, sedangkan antara perlakuan $0 \%$ dan $25 \%$ tidak menunjukkan perbedaan nyata terhadap bobot kering akar.

Salisbury dan Ross (1995) menyatakan bahwa bobot segar tanaman dapat menunjukkan aktivitas metabolisme tanaman yang dipengaruhi oleh kandungan air jaringan, unsur hara dan hasil metabolisme. Peningkatan ukuran dan jumlah sel pada akhirnya akan meningkatkan berat tanaman. Produksi tanaman lebih akurat dinyatakan dengan ukuran bobot kering karena bobot segar dipengaruhi oleh kondisi kelembaban.

Alelokimia fenol menyebabkan cekaman oksidatif tanaman sehingga produksi superoksida meningkat (gambar 1), yang menyebabkan terjadi kerusakan sel dan jaringan pada tanaman sehingga menghambat peningkatan tinggi tanaman, jumlah daun, luas daun, bobot segar dan bobot kering gulma Bidens pilosa L. Einhellig (1994) dan Rice (1984) menyatakan bahwa alelokimia memiliki pengaruh nyata dalam menghambat pembelahan sel, diferensiasi sel, penyerapan air dan ion, metabolisme fitohormon, respirasi, fotosintesis, fungsi enzim serta ekspresi gen.
Li et al (2010) menyatakan bahwa terdapat gangguan pembelahan sel dan kerusakan struktur selular pada tanaman yang terkena asam fenolik. Hal ini menyebabkan respirasi terganggu yang menurunkan laju fotosintesis, sehingga terjadi penurunan produk fotosintesis. Zhou dan $\mathrm{Yu}$ (2006) menyatakan bahwa alelokimia berpotensi mengganggu kinerja dari tiga proses utama fotosintesis yaitu kontrol stomata dalam pasokan $\mathrm{CO} 2$, transpor elektron tilakoid (reaksi terang), dan reaksi gelap.

Rice (1984) menyatakan bahwa polifenol pada tanaman seperti asam ferulat dan asam sinapic dapat menghambat pembentukan hormon pertumbuhan yaitu asam indol asetat (IAA) yang berperan dalam proses pembentukan sel. Alelokimia dapat meningkatkan proses dekarboksilasi dari IAA yang mampu menekan pertumbuhan tanaman sehingga pertambahan tinggi tanaman, luas daun serta pertambahan bobot tanaman menjadi terhambat. Pembentukan hormon pertumbuhan IAA yang terhambat juga menghambat diferensiasi daun sehingga menurunkan jumlah daun gulma Bidens pilosa $\mathrm{L}$.

Alelokimia dapat menghambat penyerapan mineral oleh akar tanaman. Menurut Zhou dan $\mathrm{Yu}$ (2006) penghambatan penyerapan ion secara langsung berhubungan dengan gangguan membran sehingga keseimbangan air terganggu dan tanaman kekurangan mineral. Alelokimia menyebabkan terganggunya akar tanaman dalam penyerapan mineral karena mampu mengubah perbedaan 
potensial elektron, menghambat ATPase, menurunkan kadar ATP seluler dan mengubah permeabilitas membran untuk ion sehingga menyebabkan pertumbuhan vegetatif tanaman terganggu. Tabel 1 menunjukkan kontrol tidak berbeda nyata dibandingkan dengan perlakuan $25 \%$ dan $50 \%$ tetapi berbeda nyata dengan perlakuan $75 \%$ dan $100 \%$, serta antara perlakuan $25 \%$ dan $50 \%$ menunjukkan perbedaan yang nyata. Semua perlakuan menunjukkan berat kering tajuk lebih besar dari berat kering akar, tetapi peningkatan rasio tajuk akar yang paling tinggi yaitu pada konsentrasi $50 \%$.

Sistem transportasi elektron akibat senyawa fenol menghasilkan ROS dengan $\mathrm{O}_{2}$ sebagai akseptor elektron. ROS seperti radikal superoksida $\left(\mathrm{O}_{2}^{-}\right)$, dihasilkan dalam kloroplas, mitokondria, peroksisom, glyoxysomes, sitosol, apoplast, nukleus dan sistem endomembran. Pada jaringan fotosintesis, kloroplas adalah sumber utama pembentukan ROS pada tanaman. Superoksida dari daun, ditransportasikan ke organ lain pada tanaman secara difusi melalui membran sel (Singh, 2016). Pada Bidens pilosa L., diduga akumulasi superoksida lebih tinggi pada akar dibandingkan tajuk, ditandai dengan penghambatan pertumbuhan akar lebih besar. Superoksida menghambat transportasi hormon auksin ke akar sehingga menghambat pembelahan sel pada akar (Cheng dan Zhihui, 2016).

Fitter dan Hay (1998) menyatakan bahwa besarnya rasio tajuk akar berkaitan dengan kemampuan absorbsi air oleh tanaman yang meningkat sebagai salah satu mekanisme untuk mempertahankan potensial air yang tetap tinggi pada saat tanaman mengalami kekurangan air. Rasio tajuk-akar digunakan untuk mengetahui kemampuan tumbuhan dalam mempertahankan keseimbangan fungsional di lingkungan yang mengalami cekaman. Menurut Beets et al. (2007), perbandingan berat kering tajuk yang lebih besar daripada akar menyebabkan terhambatnya transportasi air dan mineral pada tumbuhan yang akan menyebabkan kerusakan pada tanaman.

\section{KESIMPULAN}

Alelokimia perasan Pilea microphylla L. berpengaruh meningkatkan kandungan superoksida pada Bidens pilosa L. sehingga menghambat pertumbuhan vegetatif gulma Biden bilosa $\mathrm{L}$.

\section{DAFTAR PUSTAKA}

Bartolome, A. P., Irene M., Villaseñor. and Wen C.Y. 2013. Evidence-Based Complementary and Alternative Medicine. Hindawi Publishing Corporation, Taiwan.

Beets,P. N., S. H. Pearce, G. R. Oliver and P. W. Clinton. 2007. Root/Shoot Ratios for Deriving Below- Biomass of Pinus Radiata Stands Ground. New Zealand Journal of Forestry Science. 37(2): 267-288.

Bhaskar, A., Nithya, V. and Vidhya V.G. 2011. Phytochemical Screening and In vitro Antioxidant Activities of the Ethanolic Extract of Hibiscus rosa-sinensis L. Annals of Biological Research. 2(5): 653-661.

Cheng, F. and Zhihui C. 2016. Research Progress on the use of Plant Allelopathy in Agriculture and the Physiological and Ecological Mechanisms of Allelopathy. College of Horticulture Northwest A\&F University, China

Cnover, C.A. and R. H. Stamps. 1994. Controlling Artillery Plant (Pilea microphylla L.) with Herbicides. Jurnal University of Florida/IFAS.

Darmanti, S., Santosa, Kumala D. and L. Hartono N. 2015. Allelopathic Effect of Cyperus rotundus L. on Seed Germinationand Initial Growth of Glycine max L. cv. Grobogan. Bioma. 17 (2): 61-67

Einhellig, F.A. 1994. Allelopathy: Organisms, Processes, and Applications. American Chemical Society. Washington DC.

Fitter, A.H. dan R.K.M. Hay. 1998. Fisiologi Lingkungan Tanaman. Yogyakarta: Gadjah Mada University Press. 
Greeshma G.M., Manoj G.S. and Murugan K. 2015. RP-HPLC and FT-IR Finger Printing of Pilea microphylla (L.) Liebm. in Connection with Desiccation. Journal of Global Biosciences. 4(6): 2543-2554

Kelton, J., Andrew J., Kelton· and Jorge M. 2012. Weed Control. Intech. USA.

Li, Z., Q. Wang, X. Ruan, C. Pan, and D. Jiang. 2010. Phenolics and Plant Allelopathy. Journal Molecules. 15: 8933-8952.

Malecka, A., Piechalak, A., Zielińska, B., Kutrowska, A. and Tomaszewska, B. 2011. Response of the pea roots defense systems to the two-element combinations of metals $(\mathrm{Cu}, \mathrm{Zn}, \mathrm{Cd}, \mathrm{Pb})$. Acta Biochim Pol. 61(1): 8-23.

Nurhayati. 2011. Superoksida Dismutase (SOD) aps dan bagaimana Peranannya dalam Radioterapi. Vol. 12 no. 2.

Rice, E. L. 1984. Allelopathy. New York; Academic Press.

Riswiyanto. 2009. Kimia Organik. Erlangga. Jakarta.

Roger, M.J.R., M.J. Reigosa, N. Pedrol, and L. Gonzales. 2006. Allelopathy: Physiological Process With Ecological Implication. Springer. Netherlands.

Salisbury, F. dan Cleon W.R. 1995. Fisiologi Tumbuhan Jilid 2. Penerbit Institut Teknologi Bandung. Bandung.

Singh,R., S. Singh, P. Parihar, Rohit K., Mishra, Durgesh K., Tripathi, Vijay P., Singh, Devendra K. Chauhan and S. M. Prasad. 2016. Reactive Oxygen Species (ROS): Beneficial Companions of Plants' Developmental Processes. Front Plant Sci. 7:1299.

Yonli, D., H. Traore, P. Sereme dan P. Sankara. 2010. Use of Local Plant Aqueous Extracts as Potential Bio-Herbicides against Striga hermonthica (Del.) Benth. in Burkina Faso. Asian Journal of Corp Science. 2(3): 147154.
Zhou, Y.H. and Yu, J.Q. 2006. Allelochemicals And Photosynthesis.In: Reigosa M.J., Pedrol N., González L. (Eds). Allelopathy: A Physiological Process with Ecological Implications. 